\title{
Selection of Iron-based Additives for Enhanced Anaerobic Digestion of Sludge using the Multicriteria Decision-Making Approach
}

\author{
Samson UGWU ${ }^{1}$, Christopher ENWEREMADU ${ }^{2 *}$ \\ ${ }^{1}$ Department of Agricultural and Bioresources Engineering, University of Nigeria, Nsukka 410001, Nigeria \\ ${ }^{2}$ Department of Mechanical Engineering, University of South Africa, Science Campus, Florida 1709, \\ South Africa
}

\begin{abstract}
Enhancement of anaerobic digestion is vital for substrate solubilization and increased biogas production at a reduced cost. The use of several iron-based additives has proven effective in improving overall bio-digester performance during anaerobic digestion sludge. This study evaluates different iron-based additives for the selection of the best additive from the alternatives using a multi-attribute decision making (MADM) approach. The weights of the attributes were computed with the entropy weight technique and the ranking of the alternatives were performed using order preference by similarity to ideal solution (TOPSIS) method. Five attributes and thirteen frequently used alternatives were selected for evaluation. The result showed that additive cost and dosages were assigned the highest weight of $62.37 \%$ and $27.46 \%$, respectively. Based on the performance scores of $99.15 \%, 20 \mathrm{mg} / \mathrm{L}$ of $\mathrm{Fe}_{3} \mathrm{O}_{4}$ nanoparticles $\left(\mathrm{Fe}_{3} \mathrm{O}_{4} \mathrm{NPs}-20\right)$ ranked best (number 1$)$ among considered alternatives for enhancement of anaerobic digestion of sludge. The outcome of this evaluation agrees with previous experimental results and suggests that the choice of an effective iron-based additive should be based on its biogas enhancement potential and cost-effectiveness (low dosage requirement and low price).
\end{abstract}

Keywords - Additives; entropy method; iron-based; MADM; TOPSIS

\begin{tabular}{|lll|}
\hline Nomenclature & - \\
MADM & Multi-attribute decision making & - \\
MCDM & Multicriteria decision making & $\mathrm{g} / \mathrm{L}$ \\
nZVI & Nanoscale zero valent iron & - \\
TOPSIS & Technique for Order Preference by Similarity to Ideal Solution & - \\
WIS & Waste iron scraps & - \\
ZVI & Zero valent iron & - \\
ZVSI & Zero valent scrap iron & \\
\hline
\end{tabular}

\section{INTRODUCTION}

The unsustainable and environmentally menacing impacts of fossil energy sources have necessitated the global quest for renewable energy options. Biogas production via anaerobic

* Corresponding author.

E-mail address: enwercc@unisa.ac.za 
digestion technology is one of the many renewable alternatives with the dual role of waste management (treatment and reduction) and energy generation. Anaerobic digestion, which is a four-stage biochemical process involves the degradation of polymeric organic matter to monomers and simple molecules but is largely hampered by the nature of substrates, presence of inhibitor, nutrient deficiency, etc. [1]. The stage most affected is the hydrolysis stage, which is often referred to as the rate-limiting phase [2].

More so, due to the low substrate biodegradability occasioned by earlier mentioned challenges, various intensification strategies for improved biodegradability, reduced hydraulic retention time and increased biogas yield have been devised. These efforts include co-digestion, substrate pretreatment, additive/nutrient supplementation, etc. [1], [3]. Co-digestion of more than one substrate with complementary advantages aid maintenance of reaction $\mathrm{pH}$, attainment of appropriate carbon-to-nitrogen $(\mathrm{C} / \mathrm{N})$ ratio and other nutrient range, reduction of possible toxicity and increase in organic loading rate of the bioreactor [4], [5]. Similarly, many substrate pretreatment types have been studied and reported to have enhanced substrate solubilization and hydrolysis rate via the alteration of intercellular structures of organic matter, disruption of sludge flocs, polyvalent ions, the cell wall of organisms and extracellular polymeric substances (EPS) [6]. Different pretreatment options, which are largely selected based on their cost-effectiveness and have been used for anaerobic digestion enhancement are categorized as physical (mechanical, hydrothermal, irradiation, etc.), chemical (dilute acid, alkaline, organosolv, oxidizing agents, etc.), biological and enzymatic (bacterial and fungal) and combined (thermochemical, physicochemical, etc.) [1], [7].

Although these enhancement options could improve substrate solubilization and increase biogas production, Zhao et al. [8] reported that the increase in biogas produced as a result of these pretreatment options may not compensate for the additional energy and chemical cost. Similarly, biological pretreatment type is time-consuming and extreme $\mathrm{pH}$, salt formations and overall toxicity arising from the use of chemical pretreatment option tend to limit these options [9], [10].

Conversely, supplementation of the anaerobic digestion process with eco-friendly, cost-effective, and efficient additives as an enhancement option improves biogas quantity and quality [11], [12]. These additives aid the growth of anaerobes, enhance substrate solubilization and improve overall process biochemistry [13]. Some of these additives previously used for enhancement of anaerobic digestion are either as trace elements or nanoparticles of selenium (Se), cobalt $(\mathrm{Co})$, iron (Fe), molybdenum (Mo), etc. [4], [14]. Due to some obvious advantages such as their low cost, ease of use and access and other biochemical benefits, iron-based additives have been mostly used for anaerobic digestion enhancement [15], [16].

Furthermore, previous studies have reported on the enhancement strides of iron-based additives. Zhang et al. [17] reported that the introduction of $100 \mathrm{mg} / \mathrm{L}$ of $\mathrm{Fe}_{3} \mathrm{O}_{4}$ nanoparticles, increased methane yield from anaerobic digestion of sludge by $58.7 \%$. Similarly, Casals et al. [15] reported the use of a novel, optimal and continued release of $\mathrm{Fe}_{3} \mathrm{O}_{4} \mathrm{NPs}$ to the digester to achieve a $180 \%$ rise in biogas yield. In the same vein, the addition of $15 \mathrm{mg} / \mathrm{l} \mathrm{Fe}$ nanoparticle enhanced cattle manure by $38.2 \%$ [18] It was also reported that the use of 100 $\mathrm{mg} / \mathrm{l}$ trace iron aided the improvement of biogas recovery from food waste digestion [19]. There are varieties of iron-based additives that are being used for the enhancement of anaerobic digestion, but the selection of the appropriate iron-based additive could be a challenge due to the variation in properties and substrate types. This necessitates a systematic approach to selecting iron-based additives for the enhancement of anaerobic digestion. 
The multiple attribute decision-making (MADM) approach, which is an aspect of the multicriteria decision-making (MCDM) system, is an established system for making the best decision from varying alternatives based on quantifiable and available attributes [1], [20]. Multiple attribute decision-making has been found useful in every sphere of science, engineering and technology and fast tracks and simplifies the task of selecting among alternatives [21]. Several multiple attribute decision-making methods can be stochastic, fuzzy, deterministic, or combined in nature, include priority, outranking, distance and mixed methods [1]. The established multiple attribute decision-making techniques among others are weight product method, weight sum method, analytical hierarchical process (AHP), compromise and goal programming, elimination and choice translation reality (ELECTRE), multiple attribute utility theory (MAUT), preference ranking organization method for enrichment evaluation (PROMETHEE) and technique for order preference by similarity to ideal solution (TOPSIS) [1], [7], [20], [22], [23]. It could be observed from previous studies that TOPSIS and AHP methods are the most used for decision making.

Previously, researchers have applied multiple attribute decision-making methods in selecting the best from alternatives especially in renewable energy studies [24]. Oluah et al. [23] used both TOPSIS and entropy method to select the best phase change material (PCM) for solar energy storage with the Trombe wall. They implemented the entropy method by assigning weights to phase change material identified properties and the PCM were ranked using TOPSIS by assigning performance scores within the interval of $\{0,1\}$ for alternatives. For anaerobic digestion-related activities, Rao and Baral [20] used TOPSIS and a graphical method to rank feedstocks from available alternatives based on 30 predetermined attributes. On enhancement of anaerobic digestion, Ghandi et al. [25] reported the use of the Vise Kriterijumska Optimizacija I Kompromisno Resenje (VIKOR) technique to determine the best pretreatment on food waste for anaerobic digestion. It was observed that hotel food waste exposed to thermal pretreatment at $100{ }^{\circ} \mathrm{C}$ for 10 minutes ranked best with the VIKOR techniques and agrees with the experimental result too. Vannarath and Thalla [1] reported the evaluation and ranking of seven pretreatment methods with five attributes of lignocellulosic waste using TOPSIS and mixed technique of design of experiment and TOPSIS (DOETOPSIS). It was reported that the experimental and model results agreed with each other and showed the best pretreatment option for lignocellulosic waste for anaerobic digestion.

As shown above, studies on other forms of anaerobic digestion enhancements exist, but the absence of studies on iron-based additive selection techniques for enhancement of anaerobic digestion from available literature has necessitated this study. Selecting appropriate additive from alternatives for anaerobic digestion enhancement will improve digester performance, increase biogas yield, and reduce operational cost. Based on the available additives, six attributes vital to adjudicating the performance of biodigesters were considered in this study. This study also used entropy weight technique and TOPSIS methodology, which are novel to the selection/ranking of additive from alternatives to enhance biogas production.

\section{Methodology}

\subsection{Desirable Attributes of Anaerobic Digestion and Criteria for Additive Selection}

Suitable iron additives for the enhancement of anaerobic digestion processes must have some key features. The selected iron-additive should be of low capital and operational costs, apply to a wide range of substrates, and ultimately increase biogas yield and methane content [11]. These iron-based additives should be able to promote the growth of methanogen, facilitates direct interspecies electron transfer in syntrophic methane production, improve 
hydrolysis, solubilization and acidification stages through the dissimilatory process of iron reduction and wields great potential in the degradation of complex organics [14], [18].

Various desirable parameters/attributes on which anaerobic digestion performance is dependent include moisture content, volatile and total solids, temperature, odour, colour, volatile fatty acids (VFA), $\mathrm{C} / \mathrm{N}$ ratio, alkalinity, $\mathrm{pH}$, lignocellulosic content, biochemical oxygen demand (BOD), chemical oxygen demand (COD), heavy metals, ammonia, nature, cost, and availability of substrates, etc. [1], [20]. Similarly, the iron-additive enhanced anaerobic digestion process depends on the additive type, dosage, availability, type of substrate, cost of additives, etc. [26]. However, the selection of iron-based additive for enhanced biogas production is often based on its ability to enhance the removal of solids, increase methanogenic activities, improve system stability, increase VFA conversion and removal, increase organic loading rate, reduce hydraulic retention time, increase biogas yield, low dosage usage and low additive cost, etc. According to Cioabla et al. [27], the above-listed attributes are largely dependent on each other and variations in any affects the attribute, hence our multicriteria approach to selecting and ranking iron-based additives.

In this study, all the selected iron-additives were used for enhancement of anaerobic digestion of sludge, with attributes as categorized in Rao and Baral [20] such as physical attributes (Volatile solids removed, \%), chemical (COD removed, \%, VFA removed, \%) and others (biogas increase, $\%$, additive cost and dosage).

\subsection{TOPSIS Technique}

This technique is a widely accepted numerical method of solving multiple attribute decision-making challenges, its conceptual framework developed by Hwang and Yoon [28]. It is based on the selection of the best alternative from one with the least Euclidean distance from the positive ideal solution and the farthest Euclidean distance from the negative ideal solution [1], [23]. In this work, the TOPSIS approach was deployed for ranking iron-based additives enhanced anaerobic digestion of sludges with process performance as the attributes of interest. These procedures were followed:

1. Vital attribute selection.

2. Entropy weight determination.

3. TOPSIS analysis and priority list selection.

The attributes and alternatives of choice are depicted in Fig. 1 with a decision matrix chart.

\subsubsection{Vital Attribute Selection}

Only application-specific and relevant attributes were chosen from all the attributes stated above for iron-based enhanced anaerobic digestion. These attributes include $\%$ volatile solids (VS) removed, \% COD removed, \% VFA reduced, \% improvement in biogas yield, dosages, and additive cost. The additive costs were sourced in US dollars from Sigma-Aldrich and Indiamart, they were also calculated based on dosages of iron-based additives used by researchers cited in this work. Other less relevant attributes were not considered. 


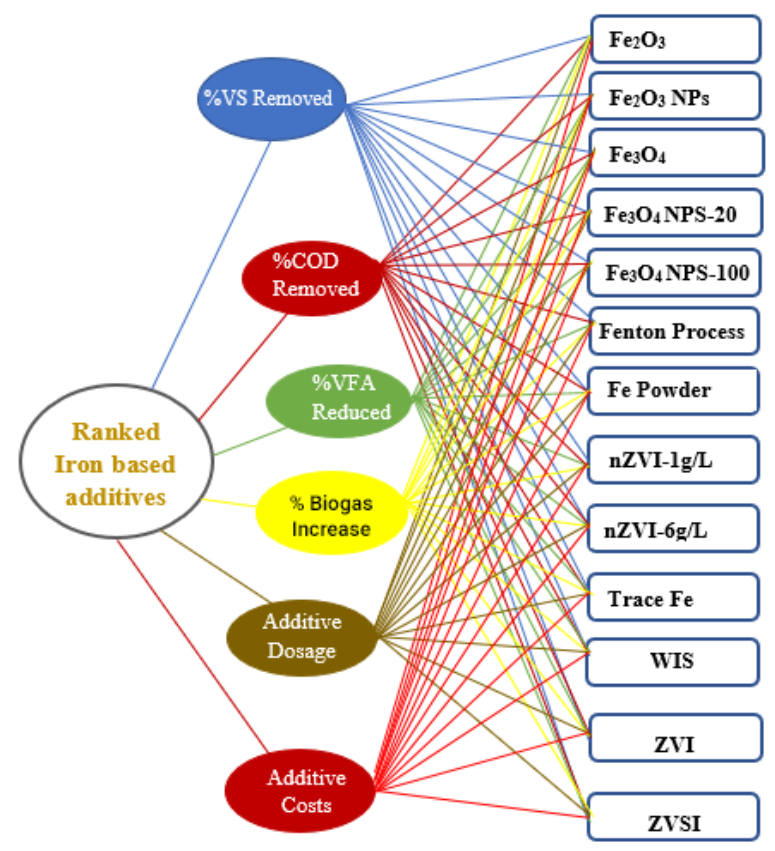

Fig. 1. Decision matrix chart for ranked iron-based additives ranking.

\subsubsection{Weight Determination by Entropy Method}

This important weight model uses the probabilistic approach to evaluate the uncertainty in information [23]. The entropy weight method has a highly objective result because its operation is largely devoid of human factor interference and dependent on the available data, hence, it better than other subjective models [29]. A decision matrix is used once there are $\mathrm{m}$ alternative and $\mathrm{n}$ attributes for the determination weights using the entropy method Eqs. (2)-(4).

The decision matrix contains the values of attributes arranged in a column and the matching of the alternatives arranged along the row to get a matrix as shown in Eq. (1).

$$
X=\left[X_{i j}\right]=\left[\begin{array}{cccc}
x_{11} & x_{12} & \ldots & x_{1 n} \\
x_{21} & x_{22} & \ldots & x_{2 n} \\
& & & \vdots \\
x_{m 1} & x_{m 2} & \ldots & x_{m n}
\end{array}\right],
$$

where, alternatives $i$ ranges from 1 to $m(1,2,3, \ldots, m)$ and its corresponding attributes $j$, ranges from 1 to $n(1,2,3, \ldots, n) . X_{i j}$, which is the performance value individual attributes represents $i$-th alternative for the $j$-th attributes.

After setting up the decision matrix, it is normalized using the procedure stated in Eq. (2).

$$
r_{i j}=\frac{x_{i j}}{\sum_{i=1}^{m} x_{i j}},
$$

where, $r_{i j}$ is the normalized decision matrix. 
The matrix is normalized by getting the ratio of each matrix value and the sum of matrix values of the column on which they belong.

Furthermore, the entropy value $e_{i j}$ is calculated using Eq. (3).

$$
e_{i j}=-h \sum_{i=1}^{m} r_{i j} \ln r_{i j},
$$

where $i=1,2, \ldots, m ; j=1,2, \ldots, n ; h=\frac{1}{\ln (m)} ; m$ is the number of alternatives.

Finally, the weight vectors $w_{i j}$ are evaluated using the below-stated expression in Eq. (4).

$$
w_{i j}=\frac{1-e_{j}}{\sum_{i=1}^{m}\left(1-e_{j}\right)},
$$

where $j=1,2, \ldots, n$.

The quantity $d_{j}=1-e_{j}$ is known as degree of diversification.

\subsubsection{TOPSIS Analysis and Selection of Priority List}

The appropriateness of the method for normalization of the decision matrix values should show in making all the attribute values to be of the same dimensionality [1]. This normalization process is carried out using Eq. (5).

$$
\bar{X}_{i j}=\frac{x_{i j}}{\sqrt{\sum_{i=1}^{m} x_{i j}^{2}}} .
$$

Next, the normalized performance values are weighted using Eq. (6).

$$
\bar{V}_{i j}=w_{j} \cdot \bar{X}_{i j},
$$

For each alternative, values are selected that are closest to the ideal best and ideal worst of the system under consideration. The Euclidean distance from the ideal best and ideal worst values are calculated using Eqs. (7) and (8), respectively.

$$
\begin{aligned}
& S_{i}^{+}=\left[\sum_{j}^{m}\left(V_{i j}-V_{j}^{+}\right)^{2}\right]^{0.5}, \\
& S_{i}^{-}=\left[\sum_{j}^{m}\left(V_{i j}-V_{j}^{-}\right)^{2}\right]^{0.5} .
\end{aligned}
$$

The performance score $P_{i}$ is calculated using Eq. (9).

$$
P_{i}=\frac{S_{j}^{-}}{S_{j}^{+}+S_{j}^{-}},
$$

The performance score is an indication of a closeness to the ideal solution, it is within an interval of $\{0,1\}$, the value closest to 1 represents the ideal best solution while the value closest 0 represents the ideal worst solution. The TOPSIS method is a multicriteria decisionmaking model with target-based criteria which makes it suitable for this work. 


\section{Results AND DiscuSSION}

The data table of the various iron-based additives and their attributes for model analysis and ranking of alternatives for enhanced anaerobic digestion of sludge are presented in Table 1. The selection of alternatives was restricted to literature information on efficiency, availability and frequency of use for anaerobic digestion of sludge. The additive costs used were average prices from reputable online stores. The six attributes were selected because their performances influence the choice of iron-based additives.

TABLE 1. SELECTED ATtRIBUteS FOR IRON-BASED AdDITIVES

\begin{tabular}{|c|c|c|c|c|c|c|c|}
\hline Additive types & $\begin{array}{l}\text { VS } \\
\text { removed, } \\
\%\end{array}$ & $\begin{array}{l}\text { COD } \\
\text { removal, \% }\end{array}$ & $\begin{array}{l}\text { VFA } \\
\text { reduced, } \\
\%\end{array}$ & $\begin{array}{l}\text { Biogas } \\
\text { increase, } \\
\%\end{array}$ & $\begin{array}{l}\text { Dosage, } \\
\text { g/L }\end{array}$ & Cost, \$ & $\begin{array}{l}\text { VS } \\
\text { removed, } \\
\%\end{array}$ \\
\hline $\mathrm{Fe}_{2} \mathrm{O}_{3}$ & 40.00 & 52.40 & 60.00 & 35.52 & 20.00 & 36.176 & [30] \\
\hline $\mathrm{Fe}_{2} \mathrm{O}_{3} \mathrm{NPs}$ & 45.00 & 90.90 & 95.52 & 35.00 & 0.75 & 1.3566 & [31] \\
\hline $\mathrm{Fe}_{3} \mathrm{O}_{4}-10 \mathrm{~g} / \mathrm{L}$ & 47.40 & 45.70 & 40.00 & 29.90 & 10.00 & 243.95 & [18] \\
\hline $\mathrm{Fe}_{3} \mathrm{O}_{4} \mathrm{NPs}-20$ & 49.88 & 52.54 & 90.00 & 73.90 & 0.02 & 0.0628 & [32] \\
\hline $\mathrm{Fe}_{3} \mathrm{O}_{4} \mathrm{NPs}-100$ & 46.90 & 76.90 & 49.00 & 58.70 & 0.10 & 0.6521 & [17] \\
\hline $\begin{array}{l}\text { Fenton Process } \\
\left(\mathrm{FeSO}_{4} \cdot 7 \mathrm{H}_{2} \mathrm{O}\right)\end{array}$ & 54.80 & 52.50 & 90.50 & 20.95 & 2.00 & 6.6319 & [33] \\
\hline Fe Powder & 49.60 & 66.20 & 70.00 & 40.80 & 5.00 & 0.6248 & [34] \\
\hline nZVI-1g/L & 23.80 & 86.60 & 80.00 & 58.44 & 1.00 & 18.207 & [35] \\
\hline nZVI-6g/L & 19.60 & 60.80 & 91.00 & 57.42 & 6.00 & 109.456 & [36] \\
\hline Trace Fe & 38.47 & 42.49 & 51.36 & 31.97 & 0.20 & 2.1468 & [37] \\
\hline WIS & 13.20 & 45.00 & 95.90 & 21.40 & 10.00 & 0.0032 & [38] \\
\hline ZVI & 42.40 & 37.00 & 88.80 & 91.50 & 10.00 & 0.8830 & [19] \\
\hline ZVSI & 52.60 & 52.90 & 62.40 & 38.30 & 1.00 & 0.0003 & [39] \\
\hline
\end{tabular}

The information in Table 1 was used for decision matrix development using Eq. (1). The matrix has column-wise attribute values and corresponding values of alternative (rowwise). In this study, a 13.6 decision matrix was formed.

However, matrix normalization for weight determination was carried out based on Eq. (2), the normalized matrix result is presented in Table 2.

TABLE 2. NORMalized Matrix TABLE With ATtRibutes

\begin{tabular}{lllllll}
\hline Additive types & $\begin{array}{l}\text { VS } \\
\text { removed, } \\
\text { \% }\end{array}$ & $\begin{array}{l}\text { COD } \\
\text { removal, } \\
\text { \% }\end{array}$ & $\begin{array}{l}\text { VFA } \\
\text { reduced, } \\
\text { \% }\end{array}$ & $\begin{array}{l}\text { Biogas } \\
\text { increase, } \\
\text { \% }\end{array}$ & $\begin{array}{l}\text { Dosage, } \\
\text { g/L }\end{array}$ & Cost, $\$$ \\
\hline $\mathrm{Fe}_{2} \mathrm{O}_{3}$ & 0.0759 & 0.0695 & 0.0622 & 0.0554 & 0.3027 & 0.0861 \\
\hline $\mathrm{Fe}_{2} \mathrm{O}_{3} \mathrm{NPs}$ & 0.0853 & 0.1206 & 0.0990 & 0.0546 & 0.0114 & 0.0032 \\
\hline $\mathrm{Fe}_{3} \mathrm{O}_{4}-10 \mathrm{~g} / \mathrm{L}$ & 0.0899 & 0.0606 & 0.0415 & 0.0466 & 0.1514 & 0.5806 \\
\hline $\mathrm{Fe}_{3} \mathrm{O}_{4} \mathrm{NPs}-20$ & 0.0946 & 0.0697 & 0.0933 & 0.1152 & 0.0003 & 0.0002 \\
\hline $\mathrm{Fe}_{3} \mathrm{O}_{4} \mathrm{NPs}-100$ & 0.0889 & 0.1020 & 0.0508 & 0.0915 & 0.0015 & 0.0016 \\
\hline $\begin{array}{l}\mathrm{Fenton} \mathrm{Process} \\
\left(\mathrm{FeSO} \mathrm{S}_{4} .7 \mathrm{H}_{2} \mathrm{O}\right)\end{array}$ & 0.1039 & 0.0696 & 0.0938 & 0.0327 & 0.0303 & 0.0158 \\
\hline $\mathrm{Fe} \mathrm{Powder}$ & 0.0941 & 0.0878 & 0.0726 & 0.0636 & 0.0757 & 0.0015 \\
\hline
\end{tabular}




\begin{tabular}{lllllll}
\hline nZVI-1 g/L & 0.0451 & 0.1149 & 0.0830 & 0.0911 & 0.0151 & 0.0433 \\
\hline nZVI-6 g/L & 0.0372 & 0.0806 & 0.0944 & 0.0895 & 0.0908 & 0.2605 \\
\hline Trace Fe & 0.0800 & 0.0458 & 0.0533 & 0.1241 & 0.0030 & 0.0051 \\
\hline WIS & 0.0250 & 0.0597 & 0.0994 & 0.0334 & 0.1514 & $7.65 \mathrm{E}-06$ \\
\hline ZVI & 0.0804 & 0.0492 & 0.0921 & 0.1427 & 0.1514 & 0.0021 \\
\hline ZVSI & 0.0998 & 0.0702 & 0.0647 & 0.0597 & 0.0151 & $7.65 \mathrm{E}-07$ \\
\hline
\end{tabular}

Again, the entropy values $e_{i j}$ were calculated based on Eq. (3) and Eq. (4) was used to compute the weight values $w_{i j}$. The results of entropy, degree of diversification and weight vectors were tabulated as shown in Table 3.

TABLE 3. NoRMALIZED DECISION TABLE With ENTROPY GENERATION

\begin{tabular}{|c|c|c|c|c|c|c|}
\hline Additive types & $\begin{array}{l}\text { VS removed, } \\
\%\end{array}$ & $\begin{array}{l}\text { COD removal, } \\
\%\end{array}$ & $\begin{array}{l}\text { VFA reduced, } \\
\%\end{array}$ & $\begin{array}{l}\text { Biogas increase, } \\
\%\end{array}$ & $\begin{array}{l}\text { Dosage, } \\
\text { g/L }\end{array}$ & Cost, \$ \\
\hline $\mathrm{Fe}_{2} \mathrm{O}_{3}$ & -0.1956 & -0.1853 & -0.1728 & -0.1602 & -0.3617 & -0.2111 \\
\hline $\mathrm{Fe}_{2} \mathrm{O}_{3} \mathrm{NPs}$ & -0.2100 & -0.2551 & -0.2290 & -0.1587 & -0.0508 & -0.0185 \\
\hline $\mathrm{Fe}_{3} \mathrm{O}_{4}-10 \mathrm{~g} / \mathrm{L}$ & -0.2166 & -0.1699 & -0.1320 & -0.1429 & -0.2858 & -0.3156 \\
\hline $\mathrm{Fe}_{3} \mathrm{O}_{4} \mathrm{NPs}-20$ & -0.2231 & -0.1856 & -0.2213 & -0.2490 & -0.0025 & -0.0013 \\
\hline $\mathrm{Fe}_{3} \mathrm{O}_{4}$ NPs-100 & -0.2152 & -0.2328 & -0.1514 & -0.2188 & -0.0098 & -0.0100 \\
\hline $\begin{array}{l}\text { Fenton Process } \\
\left(\mathrm{FeSO}_{4} \cdot 7 \mathrm{H}_{2} \mathrm{O}\right)\end{array}$ & -0.2353 & -0.1855 & -0.2220 & -0.1118 & -0.1059 & -0.0655 \\
\hline Fe Powder & -0.2223 & -0.2136 & -0.1904 & -0.1752 & -0.1953 & -0.0097 \\
\hline nZVI-1 g/L & -0.1398 & -0.2486 & -0.2065 & -0.2183 & -0.0634 & -0.1360 \\
\hline nZVI-6 g/L & -0.1224 & -0.2030 & -0.2227 & -0.2160 & -0.2179 & -0.3504 \\
\hline Trace Fe & -0.2020 & -0.1412 & -0.1562 & -0.2590 & -0.0176 & -0.0267 \\
\hline WIS & -0.0923 & -0.1682 & -0.2295 & -0.1134 & -0.2858 & $-9 \mathrm{E}-05$ \\
\hline ZVI & -0.2027 & -0.1479 & -0.2196 & -0.2778 & -0.2858 & -0.0129 \\
\hline ZVSI & -0.2299 & -0.1864 & -0.1771 & -0.1683 & -0.0634 & $-1.1 \mathrm{E}-05$ \\
\hline$e_{j}$ & 0.9775 & 0.9837 & 0.9866 & 0.9628 & 0.7586 & 0.4516 \\
\hline$d$ & 0.0225 & 0.0163 & 0.0134 & 0.0373 & 0.2414 & 0.5484 \\
\hline$W_{j}$ & 0.0256 & 0.0185 & 0.0153 & 0.0424 & 0.2746 & 0.6237 \\
\hline
\end{tabular}

It could be observed that most of the attributes showed low entropy value, according to Oluah et al. [23] may be due to the minimal difference between each value. Additive cost and dosage had the highest entropy value, this agrees with the views of Abdelsalam et al. [11] that additive price is a major choice in deciding the type of iron-based additive to be used for enhancing anaerobic digestion. Similarly, Ugwu et al. [26] reported that dosage had a major influence on the overall enhancement process, hence a deciding factor in the choice of alternatives. It is safe to say that in selecting iron-based additives for enhancement of anaerobic digestion, low dosage requirement and low cost of additives is of great importance.

The entropy weights assigned to each of the attributes were used in the TOPSIS analysis. The normalized decision matrix table was calculated with Eq. (5) and the result of the analysis was presented in Table 4. 
TABLE 4. RESUlTS OF NORMALIZED TOPSIS ANALYSIS

\begin{tabular}{lllllll}
\hline Additive types & $\begin{array}{l}\text { VS } \\
\text { removed, } \\
\%\end{array}$ & $\begin{array}{l}\text { COD } \\
\text { removal, } \\
\text { \% }\end{array}$ & $\begin{array}{l}\text { VFA } \\
\text { reduced, } \\
\text { \% }\end{array}$ & $\begin{array}{l}\text { Biogas } \\
\text { increase, } \\
\%\end{array}$ & $\begin{array}{l}\text { Dosage, } \\
\text { g/L }\end{array}$ & Cost, $\mathbf{S}$ \\
\hline $\mathrm{Fe}_{2} \mathrm{O}_{3}$ & 0.2610 & 0.2405 & 0.2173 & 0.1829 & 0.7219 & 0.1337 \\
\hline $\mathrm{Fe}_{2} \mathrm{O}_{3} \mathrm{NPs}$ & 0.2936 & 0.4171 & 0.3460 & 0.1802 & 0.0271 & 0.0050 \\
\hline $\mathrm{Fe}_{3} \mathrm{O}_{4}-10 \mathrm{~g} / \mathrm{L}$ & 0.3093 & 0.2097 & 0.1449 & 0.1539 & 0.3609 & 0.9018 \\
\hline $\mathrm{Fe}_{3} \mathrm{O}_{4} \mathrm{NPs}-20$ & 0.3255 & 0.2411 & 0.3260 & 0.3804 & 0.0007 & 0.0002 \\
\hline $\mathrm{Fe}_{3} \mathrm{O}_{4} \mathrm{NPs}-100$ & 0.3060 & 0.3529 & 0.1775 & 0.3022 & 0.0036 & 0.0024 \\
\hline $\begin{array}{l}\mathrm{Fenton} \mathrm{Process} \\
(\mathrm{FeSO}\end{array}$ & 0.3576 & 0.2409 & 0.3278 & 0.1079 & 0.0722 & 0.0245 \\
\hline $\mathrm{Fe} \mathrm{Powder}$ & 0.3236 & 0.3038 & 0.2536 & 0.2100 & 0.1805 & 0.0023 \\
\hline nZVI-1g/L & 0.1553 & 0.3974 & 0.2898 & 0.3008 & 0.0361 & 0.0673 \\
\hline nZVI-6g/L & 0.1279 & 0.2790 & 0.3296 & 0.2956 & 0.2166 & 0.4046 \\
\hline Trace Fe & 0.2751 & 0.1585 & 0.1861 & 0.40982 & 0.0072 & 0.0079 \\
\hline WIS & 0.0861 & 0.2065 & 0.3474 & 0.1102 & 0.3609 & $1.19 \mathrm{E}-05$ \\
\hline $\mathrm{ZVI}$ & 0.2767 & 0.1698 & 0.3217 & 0.4710 & 0.3609 & 0.0033 \\
\hline $\mathrm{ZVSI}$ & 0.3432 & 0.2428 & 0.2260 & 0.1972 & 0.0361 & $1.19 \mathrm{E}-06$ \\
\hline
\end{tabular}

The assigned weight to each attribute from the entropy analysis was used to calculate the weighted normalized TOPSIS table. This weighted normalization process was conducted with Eq. (6) and the resulting matrix table is shown in Table 5.

TABLE 5. WEIGHTED NORMALIZED TOPSIS TABLE

\begin{tabular}{|c|c|c|c|c|c|c|}
\hline Additive types & $\begin{array}{l}\text { VS } \\
\text { removed, } \\
\%\end{array}$ & $\begin{array}{l}\text { COD } \\
\text { removal, } \\
\%\end{array}$ & $\begin{array}{l}\text { VFA } \\
\text { reduced, } \\
\%\end{array}$ & $\begin{array}{l}\text { Biogas } \\
\text { increase, } \\
\%\end{array}$ & $\begin{array}{l}\text { Dosage, } \\
\text { g/L }\end{array}$ & Cost, \$ \\
\hline $\mathrm{Fe}_{2} \mathrm{O}_{3}$ & 0.0067 & 0.0044 & 0.0033 & 0.0078 & 0.1982 & 0.0834 \\
\hline $\mathrm{Fe}_{2} \mathrm{O}_{3} \mathrm{NPs}$ & 0.0075 & 0.0077 & 0.0053 & 0.0076 & 0.0074 & 0.0031 \\
\hline $\mathrm{Fe}_{3} \mathrm{O}_{4}-10 \mathrm{~g} / \mathrm{L}$ & 0.0079 & 0.0039 & 0.0022 & 0.0065 & 0.0991 & 0.5624 \\
\hline $\mathrm{Fe}_{3} \mathrm{O}_{4} \mathrm{NPs}-20$ & 0.0083 & 0.0045 & 0.0050 & 0.0161 & 0.0002 & 0.0002 \\
\hline $\mathrm{Fe}_{3} \mathrm{O}_{4} \mathrm{NPs}-100$ & 0.0078 & 0.0065 & 0.0027 & 0.0128 & 0.0010 & 0.0015 \\
\hline $\begin{array}{l}\text { Fenton Process } \\
\left(\mathrm{FeSO}_{4} .7 \mathrm{H}_{2} \mathrm{O}\right)\end{array}$ & 0.0091 & 0.0045 & 0.0050 & 0.0046 & 0.0198 & 0.0153 \\
\hline Fe Powder & 0.0083 & 0.0056 & 0.0039 & 0.0089 & 0.0496 & 0.0014 \\
\hline nZVI-1g/L & 0.0040 & 0.0074 & 0.0044 & 0.0127 & 0.0099 & 0.0420 \\
\hline nZVI-6g/L & 0.0033 & 0.0052 & 0.0050 & 0.0125 & 0.0595 & 0.2524 \\
\hline Trace Fe & 0.0071 & 0.0029 & 0.0028 & 0.0174 & 0.0020 & 0.0050 \\
\hline WIS & 0.0022 & 0.0038 & 0.0053 & 0.0047 & 0.0991 & $7.41 \mathrm{E}-06$ \\
\hline ZVI & 0.0071 & 0.0031 & 0.0049 & 0.0200 & 0.0991 & 0.0020 \\
\hline ZVSI & 0.0088 & 0.0045 & 0.0035 & 0.0084 & 0.0099 & $7.41 \mathrm{E}-07$ \\
\hline
\end{tabular}

Thereafter, the ideal best solution $\left(\mathrm{V}^{+}\right)$and ideal worst solution $\left(\mathrm{V}^{-}\right)$was calculated and presented in the last two rows of Table 6 . The values were computed from the weighted normalized values by determining each attribute's highest values and lowest values. Since the 
achievement of cost minimization and low dosage input is of great interest in this study, the lowest values were regarded as the ideal best solution and the highest values were the ideal worst solution [29].

The separate measure for each alternative was determined from the Euclidean distance between the alternative and its specific ideal solution. Both positive and negative separation measures for each alternative were calculated with Eq. (7) and Eq. (8) and presented in Table 6.

TABLE 6. Results of IdEAL SOLUTION $\left(\mathrm{V}^{+}\right.$AND $\left.\mathrm{V}^{-}\right)$AND EUCLIDEAN $\left(\mathrm{S}^{+}\right.$AND $\left.\mathrm{S}^{-}\right)$FROM THE IDEAL SOLUTION

\begin{tabular}{|c|c|c|c|c|c|c|c|c|}
\hline Additive types & $\begin{array}{l}\text { VS } \\
\text { removed, } \\
\%\end{array}$ & $\begin{array}{l}\text { COD } \\
\text { removal, } \\
\%\end{array}$ & $\begin{array}{l}\text { VFA } \\
\text { reduced, } \\
\%\end{array}$ & $\begin{array}{l}\text { Biogas } \\
\text { increase, } \\
\%\end{array}$ & $\begin{array}{l}\text { Dosage, } \\
\text { g/L }\end{array}$ & Cost, \$ & $\mathbf{S}^{+}$ & $\mathbf{S}^{-}$ \\
\hline $\mathrm{Fe}_{2} \mathrm{O}_{3}$ & 0.0067 & 0.0044 & 0.0033 & 0.0078 & 0.1982 & 0.0834 & 0.2153 & 0.4791 \\
\hline $\mathrm{Fe}_{2} \mathrm{O}_{3} \mathrm{NPs}$ & 0.0075 & 0.0077 & 0.0053 & 0.0076 & 0.0074 & 0.0031 & 0.0148 & 0.5910 \\
\hline $\mathrm{Fe}_{3} \mathrm{O}_{4}-10 \mathrm{~g} / \mathrm{L}$ & 0.0079 & 0.0039 & 0.0022 & 0.0065 & 0.0991 & 0.5624 & 0.5712 & 0.0993 \\
\hline $\mathrm{Fe}_{3} \mathrm{O}_{4} \mathrm{NPs}-20$ & 0.0083 & 0.0045 & 0.0050 & 0.0161 & 0.0002 & 0.0002 & 0.0051 & 0.5963 \\
\hline $\mathrm{Fe}_{3} \mathrm{O}_{4} \mathrm{NPs}-100$ & 0.0078 & 0.0065 & 0.0027 & 0.0128 & 0.0010 & 0.0015 & 0.0080 & 0.5947 \\
\hline $\begin{array}{l}\text { Fenton Process } \\
\left(\mathrm{FeSO}_{4} \cdot 7 \mathrm{H}_{2} \mathrm{O}\right)\end{array}$ & 0.0092 & 0.0045 & 0.0050 & 0.0046 & 0.0198 & 0.0153 & 0.0294 & 0.5755 \\
\hline Fe Powder & 0.0083 & 0.0056 & 0.0039 & 0.0089 & 0.0496 & 0.0014 & 0.0507 & 0.5804 \\
\hline nZVI-1g/L & 0.0040 & 0.0074 & 0.0044 & 0.0127 & 0.0099 & 0.0420 & 0.0440 & 0.5536 \\
\hline nZVI-6g/L & 0.0033 & 0.0052 & 0.0050 & 0.0125 & 0.0595 & 0.2524 & 0.2594 & 0.3398 \\
\hline Trace Fe & 0.0071 & 0.0029 & 0.0028 & 0.0174 & 0.0020 & 0.0050 & 0.0082 & 0.5912 \\
\hline WIS & 0.0022 & 0.0038 & 0.0053 & 0.0047 & 0.0991 & $7.41 \mathrm{E}-06$ & 0.1004 & 0.5711 \\
\hline ZVI & 0.0071 & 0.0031 & 0.0049 & 0.0200 & 0.0991 & 0.0020 & 0.0991 & 0.5693 \\
\hline ZVSI & 0.0088 & 0.0045 & 0.0035 & 0.0084 & 0.0099 & $7.41 \mathrm{E}-07$ & 0.0156 & 0.5932 \\
\hline $\mathrm{V}^{+}$ & 0.0091 & 0.0077 & 0.0053 & 0.0200 & 0.0002 & $7.41 \mathrm{E}-07$ & & \\
\hline $\mathrm{V}^{-}$ & 0.0022 & 0.0029 & 0.0022 & 0.0046 & 0.1982 & 0.5624 & & \\
\hline
\end{tabular}

The relationship between the Euclidean distances from the ideal best and worst solutions for iron-based additive alternatives was depicted by a comparative plot presented in Fig. 2. The complementary nature of the Euclidean distances as shown in Fig. 2 indicates the mathematical operations were accurately implemented [23]. It could be observed from the comparative plot that the performance of $\mathrm{Fe}_{3} \mathrm{O}_{4} \mathrm{NPs}-20$ and $\mathrm{Fe}_{3} \mathrm{O}_{4} \mathrm{NPs}-100$ had the shortest Euclidean distance from the ideal best solution and the widest Euclidean distance from the ideal worst solution. This according to Vannarath and Thalla [1] and Zhu et al. [29] show that $\mathrm{Fe}_{3} \mathrm{O}_{4}$ NPs-20 with the shortest distance is had the best performance among other alternatives.

Finally, the ranking of iron-based additives was based on the decrease in the suitability index value. Therefore, the alternative $\left(\mathrm{Fe}_{3} \mathrm{O}_{4} \mathrm{NPs}-20\right)$ with a performance score (highest TOPSIS score) closest to 1 was chosen as the best enhancement method. This choice also represents the ideal best solution (with the least Euclidean distance), it was presented in Table 7 together with the separation measures. The ranking with the performance scores as seen in Table 7 also agrees with the plot of Euclidean distances of idea best and worst solution.

The ranking of conductive iron oxide like $\mathrm{Fe}_{3} \mathrm{O}_{4} \mathrm{NPs}-20$ as the best alternative agrees with previous studies due to its ability to stimulate the growth of methanogens, promote the direct 
interspecies transfer of electron in syntrophic methane production, improvement of substrate solubilization, etc. [14], [18].

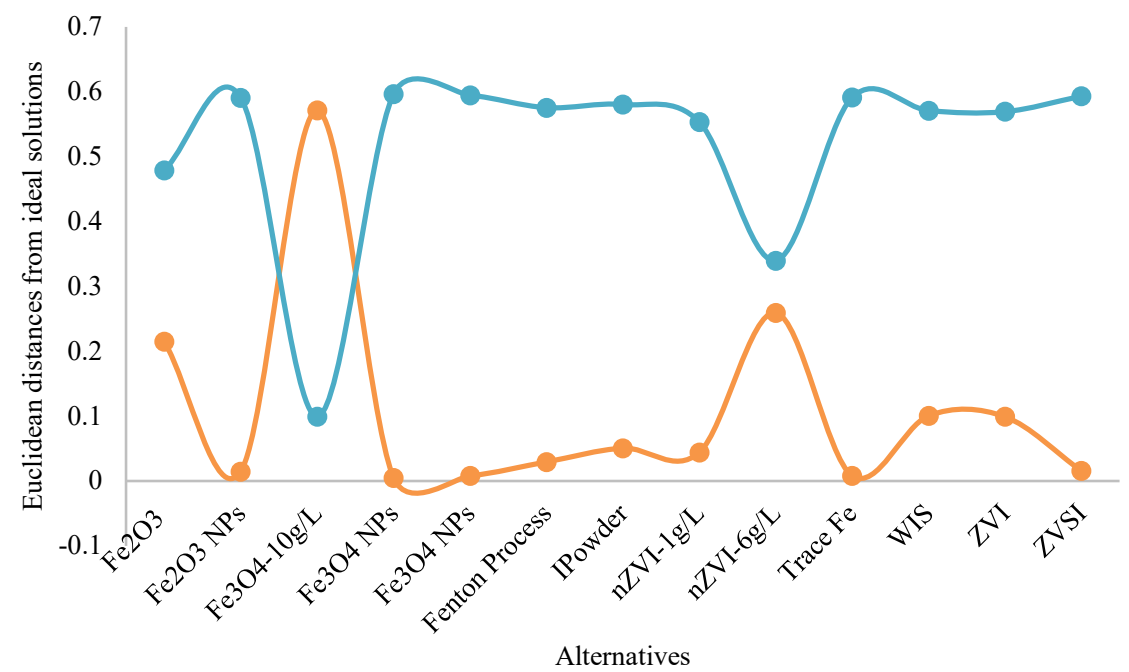

- Euclidean distance from the ideal best solution

- Euclidean distance from the ideal worst solution

Fig. 2. Comparative plot of Euclidean distances from the ideal solutions.

Table 7. Positive and Negative SeParation Measures, TOPSiS Scores AND RANKING OF ALTERNATIVES

\begin{tabular}{lllll}
\hline Additive types & $\mathbf{S}^{+}$ & $\mathbf{S}^{-}$ & $\mathbf{P i}$ & Rank \\
\hline $\mathrm{Fe}_{2} \mathrm{O}_{3}$ & 0.2153 & 0.4791 & 0.6900 & 11 \\
\hline $\mathrm{Fe}_{2} \mathrm{O}_{3} \mathrm{NPs}$ & 0.0147 & 0.5910 & 0.9757 & 4 \\
\hline $\mathrm{Fe}_{3} \mathrm{O}_{4}-10 \mathrm{~g} / \mathrm{L}$ & 0.5712 & 0.0993 & 0.1481 & 13 \\
\hline $\mathrm{Fe}_{3} \mathrm{O}_{4} \mathrm{NPs}-20$ & 0.0051 & 0.5963 & 0.9915 & 1 \\
\hline $\mathrm{Fe}_{3} \mathrm{O}_{4} \mathrm{NPs}-100$ & 0.0080 & 0.5947 & 0.9867 & 2 \\
\hline $\mathrm{Fenton} \mathrm{Process}\left(\mathrm{FeSO}_{4} .7 \mathrm{H}_{2} \mathrm{O}\right)$ & 0.0294 & 0.5755 & 0.9514 & 6 \\
\hline $\mathrm{Fe}$ Powder & 0.0507 & 0.5804 & 0.9197 & 8 \\
\hline nZVI-1g/L & 0.0440 & 0.5536 & 0.9264 & 7 \\
\hline nZVI-6g/L & 0.2594 & 0.3398 & 0.5671 & 12 \\
\hline Trace Fe & 0.0082 & 0.5912 & 0.9863 & 3 \\
\hline WIS & 0.1004 & 0.5711 & 0.8505 & 10 \\
\hline ZVI & 0.0991 & 0.5693 & 0.8518 & 9 \\
\hline ZVSI & 0.0156 & 0.5932 & 0.9744 & 5 \\
\hline
\end{tabular}


Similarly, amongst other additives studied in Abdelsalam et al. [40], it was shown that the use of $20 \mathrm{mg} / \mathrm{L} \mathrm{Fe}_{3} \mathrm{O}_{4} \mathrm{NPs}\left(\mathrm{Fe}_{3} \mathrm{O}_{4} \mathrm{NPs}-20\right)$ achieved the highest biogas yield of $584 \mathrm{~mL} / \mathrm{gVS}$ from the enhanced anaerobic digestion. Casals et al. [15] also reported a $180 \%$ rise in biogas production after supplementation of anaerobic digestion with $\mathrm{Fe}_{3} \mathrm{O}_{4}$ NPs.

\section{Conclusion}

Enhancement of anaerobic digestion is indispensable due to the limited availability of conventional feedstocks, recalcitrancy to biodegradation by the available substrates, presences of inhibitors or nutrient deficiency, etc. The selection of such appropriate enhancement for anaerobic digestion of sludges is a herculean task. In this study, the selected enhancement option (iron-based additives) was ranked using the MADM technique for the selection of the best from alternatives. The TOPSIS method and weight determination via entropy weight approach were implemented for the selection of the most suitable iron-based additive from thirteen (13) alternatives and six (6) attributes. Using the entropy method, weights were assigned to pertinent attributes (from many possible attributes) and the alternatives were ranked via the TOPSIS technique based on the performance scores (between $0,1)$. The result showed that additive cost and dosages were assigned the highest weight of $62.37 \%$ and $27.46 \%$, respectively. Based on the performance scores of $99.15 \%, 20 \mathrm{mg} / \mathrm{L}$ of $\mathrm{Fe}_{3} \mathrm{O}_{4}$ nanoparticles $\left(\mathrm{Fe}_{3} \mathrm{O}_{4} \mathrm{NPs}-20\right)$ ranked best (number 1) among considered alternatives for enhancement of anaerobic digestion of sludge. It was concluded that $\mathrm{Fe}_{3} \mathrm{O}_{4} \mathrm{NPs}-20$ with the closest score to 1 and the least Euclidean distance from the ideal best solution was selected as the best alternative (iron-based additive is most suited for enhanced anaerobic digestion of sludges for best performance. It was noteworthy that the MADM technique works well in ranking the iron-based enhancement of anaerobic digestion of sludges.

\section{ACKNOWLEDGEMENT}

This work is based on the research supported by the National Research Foundation (NRF), unique grant No. 129712.

\section{REFERENCES}

[1] Vannarath A., Thalla A. K. Evaluation, Ranking, and Selection of Pretreatment Methods for the Conversion of Biomass to Biogas Using Multi-criteria Decision-making Approach. Environment Systems and Decisions 2020:40:510-525. https://doi.org/10.1007/s10669-019-09749-9

[2] Bharathiraja B., et al. Biogas Production-A Review on Composition, Fuel Properties, Feedstock and Principles of Anaerobic Digestion. Renewable and Sustainable Energy Reviews 2018:90(C):570-582.

https://doi.org/10.1016/j.rser.2018.03.093

[3] Puyol D., et al. Exploring the Effects of ZVI Addition on Resource Recovery in the Anaerobic Digestion Process. Chemical Engineering Journal 2018:335:703-711. https://doi.org/10.1016/j.cej.2017.11.029

[4] Ugwu S. N., Enweremadu C. C. Enhancement of Biogas Production Process from Biomass Wastes Using Iron-based Additives: Types, Impacts, and Implications. Energy Sources, Part A: Recovery, Utilization, and Environmental Effects 2020. https://doi.org/10.1080/15567036.2020.1788675

[5] Ghaleb A. A. S., et al. Response Surface Methodology to Optimize Methane Production from Mesophilic Anaerobic Co-Digestion of Oily-Biological Sludge and Sugarcane Bagasse. Sustainability 2020:12(5):2116. https://doi.org/10.3390/su12052116

[6] Siami S., et al. Process Optimization and Effect of Thermal, Alkaline, $\mathrm{H}_{2} \mathrm{O}_{2}$ Oxidation and Combination Pretreatment of Sewage Sludge on Solubilization and Anaerobic Digestion. BMC Biotechnology 2020:20:1-12. https://doi.org/10.1186/s12896-020-00614-1

[7] Vamza I., Valters K., Blumberga D. Multi-Criteria Analysis of Lignocellulose Substrate Pre-Treatment. Environmental and Climate Technologies 2020:24(2):483-492. https://doi.org/10.2478/rtuect-2020-0118 
[8] Zhao Z., et al. Comparing the Mechanisms of ZVI and $\mathrm{Fe}_{3} \mathrm{O}_{4}$ for Promoting Waste-activated Sludge Digestion. Water Research 2018:144:126-133. https://doi.org/10.1016/j.watres.2018.07.028

[9] Zhang Z., et al. Impact of Pretreatment on Solid State Anaerobic Digestion of Yard Waste for Biogas Production. World Journal of Microbiology and Biotechnology 2014:30(2):547-554. https://doi.org/10.1007/s11274013-1473-3

[10] Baruah J., et al. Recent Trends in the Pretreatment of Lignocellulosic Biomass for Value-added Products. Frontiers in Energy Research 2018:6:1-19. https://doi.org/10.3389/fenrg.2018.00141

[11] Abdelsalam E., et al. Comparison of Nanoparticles Effects on Biogas and Methane Production from Anaerobic Digestion of Cattle Dung Slurry. Renewable Energy 2016:87:592-598. https://doi.org/10.1016/j.renene.2015.10.053

[12] Pastare L., Romagnoli F. Life Cycle Cost Analysis of Biogas Production from Cerathophyllum demersum, Fucus vesiculosus and Ulva intestinalis in Latvian Conditions. Environmental and Climate Technologies 2019:23(2):258271. https://doi.org/10.2478/rtuect-2019-0067

[13] Menon A., Wang J. Y., Giannis A. Optimization of Micronutrient Supplement for Enhancing Biogas Production from Food Waste in Two-phase Thermophilic Anaerobic Digestion. Waste Management 2017:59:465-475. https://doi.org/10.1016/j.wasman.2016.10.017

[14] Chen R., Konishi Y., Nomura T. Enhancement of Methane Production by Methanosarcina barkeri Using $\mathrm{Fe}_{3} \mathrm{O}_{4}$ Nanoparticles as Iron Sustained Release Agent. Advanced Powder Technology 2018:29(10):2429-2433 https://doi.org/10.1016/j.apt.2018.06.022

[15] Casals E., et al. Programmed Iron Oxide Nanoparticles Disintegration in Anaerobic Digesters Boosts Biogas Production. Small 2014:10(14):2801-2808. https://doi.org/10.1002/smll.201303703

[16] Feng Y., et al. Enhanced Anaerobic Digestion of Waste Activated Sludge by the Addition of Zero Valent Iron. Water Research 2014:52:242-250. https://doi.org/10.1016/j.watres.2013.10.072

[17] Zhang Z., et al. Application of Iron Oxide $\left(\mathrm{Fe}_{3} \mathrm{O}_{4}\right)$ Nanoparticles During the Two-stage Anaerobic Digestion with Waste Sludge: Impact on the Biogas Production and the Substrate Metabolism. Renewable Energy 2020:146:2724 2735. https://doi.org/10.1016/j.renene.2019.08.078

[18] Abdelwahab T. A. M., et al. Impact of Iron Nanoparticles on Biogas Production and Effluent Chemical Composition from Anaerobic Digestion of Cattle Manure. Biomass Conversion and Biorefinery 2020. https://doi.org/10.1007/s13399-020-00985-7

[19] Zhang W., Zhang L., Li A. Enhanced Anaerobic Digestion of Food Waste by Trace Metal Elements Supplementation and Reduced Metals Dosage by Green Chelating Agent [S, S]-EDDS via Improving Metals Bioavailability. Water Research 2015:84:266-277. https://doi.org/10.1016/j.watres.2015.07.010

[20] Rao P. V., Baral S. S. Attribute-based specification, comparison and selection of feedstock for anaerobic digestion using MADM approach. Journal of Hazardous Materials 2011:186(2-3):2009-2016. https://doi.org/10.1016/j.jhazmat.2010.12.108

[21] Ashby M. F. Multi-objective Optimization in Material Design and Selection. Acta Materialia 2000:48(1):359-369. https://doi.org/10.1016/S1359-6454(99)00304-3

[22] Pohekar S. D., Ramachandran M. Application of Multi-criteria Decision Making to Sustainable Energy Planning-A Review. Renewable and Sustainable Energy Reviews 2004:8(4):365-381. https://doi.org/10.1016/j.rser.2003.12.007

[23] Oluah C., Akinlabi E. T., Njoku O. H. Selection of Phase Change Material for Improved Performance of Trombe Wall Systems Using the Entropy Weight and TOPSIS Methodology. Energy \& Buildings 2020:217:109967. https://doi.org/10.1016/j.enbuild.2020.109967

[24] Bumbiere K., et al. Ranking of Bioresources for Biogas Production. Environmental and Climate Technologies 2020:24(1):368-377. https://doi.org/10.2478/rtuect-2020-0021

[25] Ghandi P., et al. Multicriteria Decision Model and Thermal Pretreatment of Hotel Food Waste for Robust Output to Biogas: Case Study from City of Jaipur, India. BioMed Research International 2018:9416249. https://doi.org/10.1155/2018/9416249

[26] Ugwu S. N., Biscoff R. K., Enweremadu C. C. A Meta-analysis of Iron-based Additives on Enhancements of Biogas Yields During Anaerobic Digestion of Organic Wastes. Journal of Cleaner Production 2020:269:122449. https://doi.org/10.1016/j.jclepro.2020.122449

[27] Cioabla A. E., et al. Comparative Study on Factors Affecting Anaerobic Digestion of Agricultural Vegetal Residues. Biotechnol Biofuels 2012:5(39). https://doi.org/10.1186/1754-6834-5-39

[28] Hwang C. L., Yoon K. Multiple Attribute Decision Making Methods and Applications. Berlin: Springer-Verlag, 1981.

[29] Zhu Y., Tian D., Yan F. Effectiveness of Entropy Weight Method in Decision-making. Mathematical Problems in Engineering 2020:3564835. https://doi.org/10.1155/2020/3564835

[30] Ye J., et al. Enhancing Sludge Methanogenesis with Improved Redox Activity of Extracellular Polymeric Substances by Hematite in Red Mud. Water Research 2018:134:54-62. https://doi.org/10.1016/j.watres.2018.01.062

[31] Ambuchi J. J., et al. Hematite and Multi-walled Carbon Nanotubes Stimulate a Faster Syntrophic Pathway during Methanogenic Beet Sugar Industrial Wastewater Degradation. Applied Microbiology and Biotechnology 2018:102:7147-7158. https://doi.org/10.1007/s00253-018-9100-8

[32] Aguilar-Moreno G. S., et al. Enhancing Methane Yield of Chicken Litter in Anaerobic Digestion Using Magnetite Nanoparticles. Renewable Energy 2020:147:204-213. https://doi.org/10.1016/j.renene.2019.08.111 
[33] Wang M., Zhao Z., Zhang Y. Sustainable Strategy for Enhancing Anaerobic Digestion of Waste Activated Sludge: Driving Dissimilatory Iron Reduction with Fenton Sludge. ACS Sustainable Chemical Engineering 2018:6:222-02230. https://doi.org/10.1021/acssuschemeng.7b03637

[34] Suanon F., et al. Application of Nanoscale Zero Valent Iron and Iron Powder During Sludge Anaerobic Digestion: Impact on Methane Yield and Pharmaceutical and Personal Care Products Degradation. Journal of Hazardous Materials 2017:321:47-53. https://doi.org/10.1016/j.jhazmat.2016.08.076

[35] Amen T. W., et al. Biochemical Methane Potential Enhancement of Domestic Sludge Digestion by Adding Pristine Iron Nanoparticles and Iron Nanoparticles-coated Zeolite Compositions. Journal of Environmental Chemical Engineering 2017:5(5):5002-5013. https://doi.org/10.1016/j.jece.2017.09.030

[36] Lizama A. C., et al. Enhancing the Performance and Stability of the Anaerobic Digestion of Sewage Sludge by Zero Valent Iron Nanoparticles Dosage. Bioresource Technology 2019:275:352-359. https://doi.org/10.1016/j.biortech.2018.12.086

[37] Yu B., et al. Variations of Organic Matters and Microbial Community in Thermophilic Anaerobic Digestion of Waste Activated Sludge with the Addition of Ferric Salts. Bioresource Technology 2015:179:291-298. https://doi.org/10.1016/j.biortech.2014.12.011

[38] Hao X., et al. Analysing the Mechanisms of Sludge Digestion Enhanced by Iron. Water Research 2017:117:58-67. https://doi.org/10.1016/j.watres.2017.03.048

[39] Zhen G., et al. Influence of zero valent scrap iron (ZVSI) supply on methane production from waste activated sludge. Chemical Engineering Journal 2015:263:461-470. https://doi.org/10.1016/j.cej.2014.11.003

[40] Abdelsalam E., et al. Influence of Zero Valent Iron Nanoparticles and Magnetic Iron Oxide Nanoparticles on Biogas and Methane Production from Anaerobic Digestion of Manure. Energy 2017:120:842-853.

https://doi.org/10.1016/j.energy.2016.11.137 